\title{
Função social em “vintém de cobre: meias confissões de aninha”, de Cora Coralina
}

\author{
Évelin da Silva Krol ${ }^{1}$ \\ Juarez Poletto ${ }^{2}$
}

\section{Resumo}

Este trabalho estuda a poesia de "Vintém de cobre: meias confissões de Aninha", de Cora Coralina, para verificar como se concretiza a função social da poesia, segundo Eliot, na construção de imagens do Brasil. Para isso se analisa a linguagem e a temática bem como a função da memória na referida obra, que representa a vida comum de seres marginalizados. A autora se utiliza tanto da linguagem da oralidade do meio representado, quanto de recursos mais sofisticados, relativos à sua condição de poeta. Através da reconstrução da memória, mesmo que não seja representação fiel dos fatos, a obra recria o modo de ver o mundo desse grupo social, do qual o eu lírico faz parte. Através da representação ficcional desse modo de vida, da sua linguagem e do modo desse grupo social ver o mundo, Cora Coralina reconta parcela da História do Brasil.

Palavras-chave: Cora Coralina. Poesia. Função social. Memória.

\begin{abstract}
This work studies the poetry "Vintém de cobre: meias confissões de Aninha" (Vintém copper: half confessions of Annie) by Cora Coralina, analy sing how it deals with the social function of the poetry, according to Eliot, in constructing images of Brazil. In order to do this we analyze the language and the theme as well as the role of memory in that work, which represents the common life of outcasts. The author uses the sprium of language of the represented environ ment orality, as well sophisticated features related to her status as a poet. Through the reconstruction of the memory, even if not a faithful representation of the facts, the work recreates the way of seeing the world in this social group, which is part of the lyrical self. Through the fictional representation of this way of life, her language and way this social group sees the world, Cora Coralina plot recounts the history of Brazil.
\end{abstract}

Keywords: Cora Coralina. Poetry. Social function. Memory.

\section{Introdução}

Neste trabalho procura-se evidenciar o quanto a obra poética "Vintém de cobre: meias confissões de Aninha”, de Cora Coralina (Ana Lins do Guimarães Peixoto Bretas), contém de traços que reescrevem o Brasil através da reconstrução da memória do ‘eu poético’.

\footnotetext{
${ }^{1}$ Especialista. E-mail: vecakrol@bol.com.br, veca.krol@yahoo.com.br

${ }^{2}$ Doutorado em Letras pela Universidade Federal do Paraná, Brasil (2007). Professor do Ensino Tecnológico da Universidade Tecnológica Federal do Paraná, Brasil. E-mail: jpoletto52@gmail.com
} 
A obra reescreve o país quando reconta como os brasileiros viviam no final do século XIX e início do XX, recontando costumes que permaneceram por muitas décadas posteriores, alguns persistindo na atualidade.

A recriação do Brasil via poesia se faz no estilo de contar casos, ato comum no povo que a obra focaliza: os habitantes de zonas rurais, cuja linguagem informal e típica do meio acentua um modo de vida, o que destaca o foco temático da obra, o povo rural, e o que determina o seu caráter social. Esse caráter social se acentua por a obra tratar de seres marginalizados, como as mulheres, meninas e lavradores. Para tratar desses temas, os poemas fazem uma longa narração do espaço em que vivem essas pessoas, para mostrar o ambiente e o modo de vida em que estão inseridas.

Mas a obra "Vintém de cobre: meias confissões de Aninha" não pode ser entendida na sua integridade se procurarmos nela somente o que ela exprime da realidade, ou seja, somente seu caráter sociológico, como alguns teóricos interpretaram as obras associadas a um tempo. Um desses teóricos é Sartre que, em “Que é a literatura?” defende que uma função importante da literatura é o engajamento, mas afirma que a poesia não serve para o engajamento, porque considera que ela não trabalha com a palavra como um signo, e sim como coisa. Em "Vintém de cobre: meias confissões de Aninha”, a palavra é também signo, sem perder sua característica poética de coisa, pois em muitos poemas ocorrem críticas sociais e apelos diretos ao leitor. A obra trata de poemas que visam à representação de uma parte da sociedade, o que é uma forma de engajamento. Também não poderíamos analisar essa obra somente pelas operações formais, ignorando o sociológico, porque ele desencadeia o lirismo e faz com que a poesia se crie, embora não seja as alterações nesse externo o objetivo final da obra. "Vintém de cobre: meias confissões de Aninha” precisa do texto e do contexto para ser entendida; este estudo privilegiará o contexto. O texto será analisado na medida em que importe para o contexto, como ocorre com a linguagem informal e o estilo de contar casos, que representam também o povo rural de que a obra trata. Iniciamos por alguns aspectos da linguagem.

\section{Aspectos formais de vintém de cobre}

“Vintém de cobre: meias confissões de Aninha” apresenta um estilo bastante informal, seja pela linguagem ou pelo estilo dos poemas. 
Os poemas apresentam narrações de casos ocorridos na infância do eu lírico através de cenas cotidianas, com uma aparente informalidade, pautada na oralidade.

A maior parte dos poemas é constituída de narrações, onde o eu lírico, relatando situações particulares, narra casos comuns a todo um povo que viveu na referida época e naquelas condições, são os casos da memória coletiva.

As primeiras críticas com relação à obra de Cora Coralina foram negativas em relação a esse fato, diziam que faltava densidade poética nos versos devido ao excesso de narrações.

\begin{abstract}
A crítica, em Goiás, após a estréia de Cora Coralina em 1965, naturalmente muito antes de ela ser proclamada por Drummond, em 1980, como a pessoa mais importante de nosso estado (a partir de quando o que se ouviu foi o silêncio), fez restrições ao tom lírico narrativo de seus poemas. Quase todos os críticos, quando não lhe torciam o nariz, batiam na mesma tecla: 'é mais prosadora, do que poeta'. (BRITTO, 2009, p. 4)
\end{abstract}

A narração não impede a poeticidade da obra, porque dentro dessas narrações pode haver o poético, como se percebe no poema "Três deveres a cumprir" na narração do trabalhador pobre que ajudou outro trabalhador.

$[\ldots]$

Um dia entrei num rancho que tinha cedido

Para um trabalhador "bater" um capoeirão do vizinho.

Olhei, num canto a trempe apagada,

Um caldeirão de feijão e carne seca cozidos pela metade.

E a cama? Um jirau de forquilhas, no lastro, paus roliços,

De forro algumas folhas secas de bananeira,

Travesseiro - uma telha retirada do beiral do rancho.

Esse mesmo trabalhador chamou um ajudante para apressar o trabalho.

De mau jeito foi alcançado por um pé de pau.

O medo da responsabilidade no caso da invalidez do companheiro,

Internamento, médico, remédios, dias pagos.

Foram à cidade. Indiquei um médico amigo no sentido de melhorar a [situação.

Voltaram, nenhuma fratura, repouso apenas de uns dias.

Nosso sítio tinha abrigo disponível.

Um trabalhador ofereceu ao ofendido a própria cama e seus panos.

Fui ver o doente e o que encontro: o dono da cama com uma bacia [d’água

Lavando os pés do machucado para que não lhe sujasse as cobertas.

Ele, o samaritano, já tinha arrumado uns baixeiros para dormir no chão

Ao lado da cama.

Estas e outras coisas do viver dos humildes.

$[\ldots]$

Essas narrações fazem com que o estilo do poema seja semelhante ao contar de casos, típicos das populações rurais, que é um dos focos temáticos centrais das obras da autora, combinados com uma linguagem semelhante com a usada por esse povo. 
Não sem motivos Coralina se tornou uma exímia contadora de casos, de "conversas infindáveis de outros tempos”. Ao lê-la, lembramos as lições de Walter Benjamin (1985) quando em O Narrador ressalta que o ato de narrar consiste na faculdade de intercambiar experiências. Desse modo, a fonte de todos os narradores seria a experiência que é transmitida de pessoa a pessoa. Narrativa que não estaria interessada em "transmitir o 'puro em si' da coisa narrada como uma informação ou um relatório. Ela mergulha a coisa na vida do narrador para em seguida retirá-la dele. Assim se imprime na narrativa a marca do narrador, como a mão do oleiro na argila do vaso (DELGADO, 2003, p. 205).

TS Eliot, em “A função social da poesia”, defende que os escritores devem usar a língua como ela é falada no momento e ressalta a importância da poesia no desenvolvimento de uma cultura nacional.

[...] o poeta deve usar como material sua própria língua como está sendo falada no momento. (ELIOT, 1991, p. 38)

[...] a poesia está primeiramente ligada à expressão dos sentimentos e das emoções, e que sentimentos e essas emoções são particulares, embora isso seja geral. É mais fácil pensar em uma língua estrangeira do que sentir nela. Portanto nenhuma arte é mais obstinadamente nacional do que a poesia. (ELIOT, 1991, p. 33).

Em "Vintém de cobre: meias confissões de Aninha” o eu lírico usa uma linguagem como a que é usada no momento. Sendo também simples e clara, sem rebuscamentos, mas com correção gramatical. Essa linguagem também contém palavras e expressões comuns no ambiente rural, pois está sempre tratando desse mundo, o que ajuda na oralidade presente nesses poemas. Com essa linguagem ocorre uma forma de expressão da nacionalidade e a função social da poesia, porque mostra nossas expressões, principalmente as comuns em um espaço rural. Essa linguagem expressa o modo de vida de um povo, e por meio dela que se produz a poeticidade dessa expressão, porque ela é a linguagem usada por esse povo. O vocabulário simples dos poemas faz com que se revele melhor a realidade que tratam: a realidade do dia a dia, pois não poderia tratar do cotidiano com termos sofisticados, principalmente por ser uma realidade de um espaço rural, de onde deriva também a escolha por expressões típicas do mundo sertanejo, como se pode observar no poema "Três deveres a cumprir”, quando o ‘eu lírico’ usa as palavras “rancho”, “capoeirão”, “jirau de forquilha”, “trempe” e a expressão "bater um capoeirão”.

Em alguns poemas, o eu lírico defende claramente seu ponto de vista sobre a linguagem, como ocorre no poema "Meu vintém perdido", onde, nas últimas estrofes, afirma que não se pode escrever de qualquer jeito, sem correção, mas que a linguagem deve ser clara, simples e também coloquial, pois não deve deixar de lado as variações sociais e regionais: 
$[\ldots]$

Detesto os que escrevem mal e publicam livros.

A linguagem escrita, simples e correta, deve dar a impressão

De alguém que sabe escrever.

A maior dificuldade para mim sempre foi escrever bem.

A minha maior angústia foi superar a minha ignorância.

Confesso com humildade essas verdades simples e grandes.

Sou mulher operária e essa segurança me engrandece,

É o meu apoio e uma legitimação do que sou realmente.

A linguagem errada dos humildes tem para mim um gosto de terra

E chão molhado e lenha partida.

Jamais procurei corrigi-los como jamais tolerei o bem falante, exibido.

Já o nordestino, mesmo analfabeto, tem uma linguagem corrente,

Fácil e floreada, encenada nos arcaísmo do idioma.

Tive uma empregada que só dizia "meicado".

Outra que teimou sempre em me dizer "Dona Coria".

Não criei obstáculos nem propus conserto. No fim,

Quando me dirigia à primeira eu dizia: vai ao "meicado",

Com medo que ela se corrigisse. Achava aquilo saboroso,

Como saborosa sempre me pareceu a linguagem dos simples.

Tão fácil, espontânea e pitoresca nos seus errados.

Essa linguagem, com correções gramaticais, mostra uma escritora que trabalha com a linguagem para produzir efeitos de simplicidade, mas que contém um nível vocabular acima da realidade simplória que mostra. No poema "Menina mal amada” há palavras não tão simplórias e pouco usadas pela maioria dos sertanejos, como "aguçando" e “circunscrita”.

Essa linguagem informal está associada ao desejo de registrar imagens de um tempo e de um espaço, pois essa linguagem traz as marcas desse espaço e desse tempo. No poema " $\mathrm{O}$ triângulo da vida”, ocorre a adoção de palavras e expressões antigas, pertencentes à infância, portanto condizentes com o tempo em que está sendo narrado, e vê nessas palavras e expressões a mesma poeticidade que vê nos usos coloquiais novos, também porque usa essa linguagem antiga.

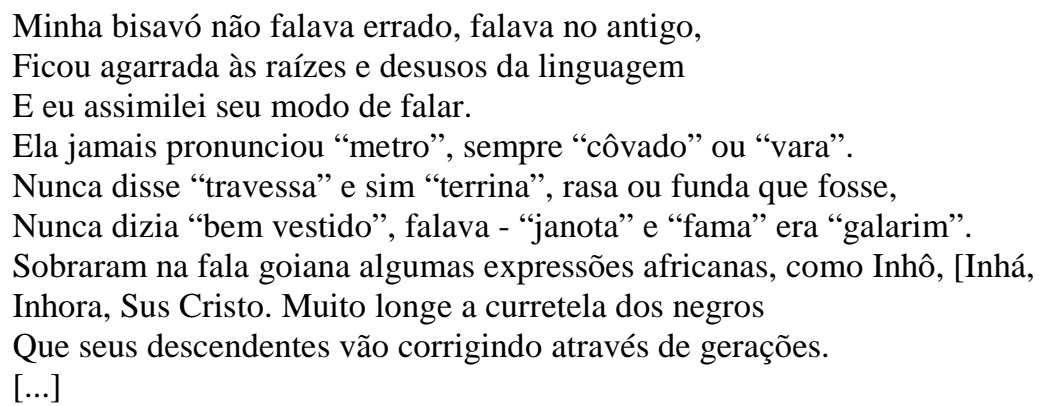

Com isso, pode-se afirmar que a poesia de Cora Coralina dá um valor poético a essa linguagem simples e coloquial, mas essa linguagem não é o único ingrediente para produzir sua poesia. Em "Vintém de cobre: meias confissões de Aninha” a poesia é produzida através de uma linguagem poética e também através de um entendimento novo de situações comuns, 
ou seja, é uma poesia produzida através de sua forma e de seu conteúdo, estando ambos inseparáveis.

\section{Construção da memória e da história}

Na obra poética "Vintém de cobre: meias confissões de Aninha”, Cora Coralina procura recriar poeticamente um tempo passado, contando sobre a infância de Aninha, uma menina do sertão. Recriando poeticamente esse passado de Aninha, o eu lírico resgata não só a sua memória, como também a memória da sociedade.

O objeto da escrita de "Vintém de cobre: meias confissões de Aninha" é fruto da experiência da autora no interior de Goiás, pois foi lá que ela passou a sua infância. Poucos poemas remetem ao tempo que ela viveu no interior de São Paulo, e estes assumem um caráter mais épico que memorialístico.

Muitos textos têm sua virtude poética também por serem textos de memória, e então revelam a diferença entre o Passado e o Presente. O que foi lembrado pode ser visto como uma chave para o que veio antes e depois, e sempre está carregado de impressões.

Nas lacunas, a memória sonha, cria impressões e, principalmente, as imprecisões da referencialidade do vivido. É nesse sentido que se pode dizer que o homem que recorda se recompõe incessantemente como ser poético. (CAMARGO, 2002, p. 75)

Como o livro trata da recriação do passado, nem tudo que está no livro pode ser visto como realidade, pois é memória construída a partir do real, dos desejos e do imaginário. Na peça “Vestido de noiva”, de Nelson Rodrigues, é possível ver essa reconstrução da memória através dos sonhos e da realidade, pois a personagem central demora para descobrir se suas recordações são ilusões ou verdades. “Vintém de cobre: meias confissões de Aninha” pode ser visto por esse lado no sentido que a lembrança não é só o real, mas está carregada de impressões somadas à distância temporal e à fantasia.

Em alguns depoimentos Cora Coralina trata do que ela entende como escritos memorialísticos, e afirma que nem tudo está marcado pelo realismo:

Muitas pessoas - conta Cora Coralina - me perguntam se o que escrevo é verdade ou imaginação. Eu tenho grande dificuldade em responder. [...] A escritora afirma não ser nenhuma historiadora ou pesquisadora. Só sei contar verdades e mentiras, que é do que os leitores gostam. Não tenho compromisso nenhum com a verdade dos fatos. Por acaso aparecerá uma verdade, mas que estará sempre revestida de uma mentira. (DELGADO, 2003, p. 285) 
Para quem escreve memórias, onde acaba a lembrança? Onde começa a ficção? Talvez sejam inseparáveis. Os fatos da realidade são como pedra, tijoloargamassados na parede, virados parede, casa, pelo saibro, pela cal, pelo reboco da verossimilhança - manipulados pela imaginação criadora. (DELGADO, 2003, p. 285)

Por "Vintém de cobre: meias confissões de Aninha” estar bastante atrelado à memória coletiva, ao social, esse processo de reconstrução se torna importante, porque carrega as impressões não só do eu lírico, mas de várias vozes que eram excluídas e viveram em um espaço semelhante. Por isso, pode-se dizer que não é só uma memória individual, mas também coletiva.

A dúvida se a realidade inteira está ali, principalmente com relação às confissões, vem devido às convenções sociais, pois elas não permitem que se trate de todo o real, mesmo que o livro trate de confissões, que geralmente possuem menos conveniências do que algo que não seja uma confissão. Por isso o livro se intitula de “meias confissões de Aninha” e não de confissões inteiras.

\footnotetext{
O vintém de cobre é uma moeda preta, antiga, que havia na minha infância. No livro eu conto as confissões de Aninha, mas não completas. Ninguém conta tudo porque temos medo. Temos três medos: medo dos mortos, medo dos vivos e medo de nós mesmos. As revelações não doem, apenas não saem por inteiro. Nem eu nem ninguém consegue contar tudo. Quem tem a coragem de dizer tudo por inteiro? (O GLOBO, 1982, p. 27)
}

Pela escritora Ana Lins do Guimarães Peixoto Bretas assinar como Cora Coralina e Aninha, é possível perceber a tentativa de afastamento do puramente biográfico e a aproximação da ficcionalização.

Assumindo o pseudônimo de Cora Coralina, a autora adota a imagem da velhinha que vendia doces e fazia versos, e adotando o nome de Aninha, a autora assume a voz da criança; como essas vozes são consideradas periféricas em nossa sociedade, não precisa recorrer tanto às convenções. Mesmo assim, no poema “Confissões partidas”, o eu lírico afirma que é dono só de meias verdades, porque entre ele e a verdade “inteira e nua” estão as conveniências, os preconceitos, as "reservas profundas”, os “reservatórios secretos, complexos, fechados”, os “compromissos íntimos”, as “algemas mentais”, o medo dos vivos, dos mortos e do próprio “eu”. Afirma que só os loucos têm o poder de falar só a verdade. Coloca essas meias verdades ao lado da mentira (terceiro verso, primeira estrofe) e da covardia (última estrofe). Portanto o livro só poderá tratar dessas meias verdades.

O poema "Este livro, meias confissões de Aninha", que inicia o livro "Vintém de cobre: meias confissões de Aninha”, procura esclarecer de que trata o livro. Afirma que é um 
livro que trata das lembranças que foram aparecendo e que busca recriar e poetizar a vida, portanto, não necessariamente tratar do real.

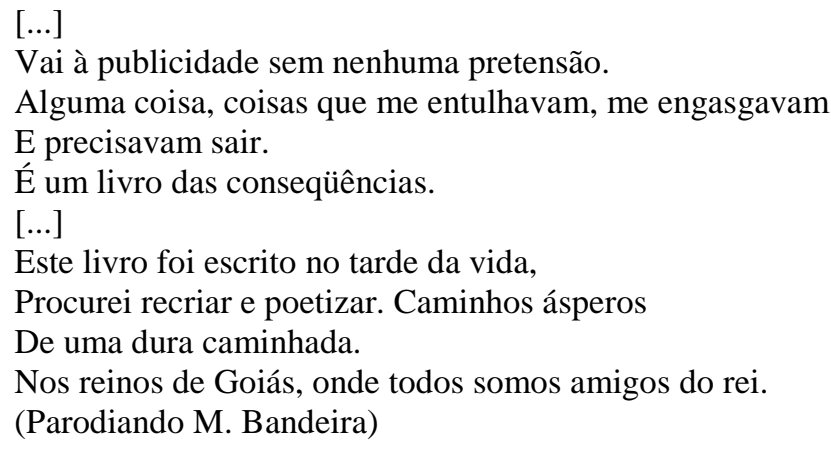

Com isso pode-se depreender que "Vintém de cobre: meias confissões de Aninha” traz aspectos psíquicos, mas esse psíquico se insere no social porque ele está constituído de aspectos sociais, como a pobreza, os decorrentes da Educação e os decorrentes de passagens históricas, como dos resquícios da escravidão. São marcas que podemos dizer que fazem parte de uma "memória coletiva”, pois além de serem pessoais são típicos de um determinado momento e de um determinado espaço. Essas marcas estão presentes em poemas como "Moinho do tempo", onde se vê o medo de não se casar, que era uma regra do tempo, a pobreza disfarçada em classe média e os resquícios da escravidão:

[...]

A gente era moça do passado.

Namorava de longe, vigiada.

Aconselhada. Doutrinada dos mais velhos,

Em autoridade, experiência, alto saber.

"moça para casar não precisa namorar,

O que for seu virá".

Ai, meu Deus! E como custava chegar...

Virá! Virá! ...Virá virá...quando?

E o tempo passando e o moinho dos anos moendo,

E a roda-da-vida rodando...Virá-virá!

A gente ali, na estaca, amarrada, consumida

De Maria Borralheira, sem madrinha-fada,

Sem sapatinho perdido,

Sem arauto de príncipe-rei, a procurar

Pelos reinos da cidade de Goiás

O pezinho faceiro do sapatinho de cristal,

Caído na correria da volta

[...]

Tudo economizado, aproveitado.

Tudo ajudava a pobreza daquela classe média, coagida, forçada

A manter as aparências de decência, compostura, preconceito,

Sustentáculos da pobreza disfarçada.

Classe média do após treze (13) de maio.

Geração ponte, eu fui, posso contar. 
Devido a essa recriação do passado e contraposição com o presente, a autora passou a ser vista como símbolo da cidade de Goiás, desde o tempo em que estava viva, o que foi ressaltado depois de 2001, quando a cidade de Goiás foi vista pela Unesco (Organização das Nações Unidas para a Educação, Ciência e Cultura) como "Patrimônio da humanidade”. Devido a isto, Andréa Delgado, em suas teses sobre a cidade de Goiás e sobre Cora Coralina, trata de uma "monumentalização" da autora.

Esse reconhecimento apenas se iniciou quando Carlos Drummond de Andrade escreveu e publicou algumas cartas falando bem dos escritos de Cora Coralina, até então ela sofria preconceito por vários motivos, principalmente por ser mulher. Drummond a coloca como patrimônio de Goiás, também a monumentalizando, e destaca em seus poemas a contraposição do passado com o presente e o tratamento especial dado às pessoas humildes e colocadas à margem.

$[\ldots]$

Na estrada que é Cora Coralina passam o Brasil velho e o atual, passam as crianças e os miseráveis de hoje. O verso é simples, mas abrange a realidade vária [...].(CORALINA, 1984, p. 27)

Seu "Vintém de cobre" é, para mim, moeda de ouro, e de um ouro que não sofre as oscilações do mercado. É poesia das mais diretas e comunicativas que já tenho lido e amado. Que riqueza de experiência humana, que sensibilidade especial e que lirismo identificado com as fontes da vida! Aninha hoje não se pertence. É patrimônio de todos nós, que nascemos no Brasil e amamos a poesia [...] (CORALINA, 1984, p. 17)

Quando a autora retornou a Goiás foi viver na mesma casa em que passou a sua infância, que é bastante citada em seus poemas, e essa casa passou a ser um ponto turístico por ter o presente e o passado fundidos. Muitas pessoas iam para lá para ouvir suas histórias, que tratavam principalmente dos costumes de uma Goiás antiga e, como em seus poemas, era possível observar o passado dentro de presente. Quando Cora Coralina morreu, a sua casa virou museu e as pessoas que conviveram com ela continuam lá para receber os visitantes e contar histórias, ou “estórias”, como a autora gostava de frisar.

Em todos seus livros, o eu lírico procura 'escrever e assinar os autos do Passado/antes que o Tempo passe tudo a raso’ ao compor poemas e contar histórias cujos enredos emergem do jogo da linguagem com as múltiplas camadas do tempo, interligando o passado, o presente e o futuro pela memória que reconstitui os espaços da cidade de Goiás.

Como afirma Clóvia de Carvalho Britto e Robson dos Santos, em ”Representações sociais do rural na poética de Cora Coralina”, com o passar do tempo, um determinado testemunho acaba sendo o registro de muitos testemunhos, as particularidades de cada um acabam se dissolvendo um pouco nas características gerais de uma geração, de uma determinada época. Sobre esse prisma pode-se olhar a obra "Vintém de cobre: meias confissões de Aninha", de Cora Coralina, como um 
registro histórico do final do século XIX e de grande parte do século XX (DELGADO, 2003, p. 285).

Toda essa recriação do seu passado trata não só do individual, mas também do que é histórico, ou do que pode ser visto como marcas do que é social na obra, quando trata dos costumes, do imaginário e das relações cotidianas comuns em um espaço rural. O livro todo mostra as marcas desses costumes, seja por meio da imposição dos comportamentos, como está no poema "Normas da Educação", onde há o lamento pelos modos como se dava a educação, ou sendo pela vivência, como está no poema “A gleba me transfigura”, que adota uma postura bastante comum em espaços rurais, de valorização da terra e do que dela nasce, e dos trabalhadores rurais, afirmando-se Aninha como parte desse espaço.

Nessa recriação da história e do espaço, pode-se perceber um período de transição dos costumes, do Brasil do final do século XIX para o Brasil da atualidade, pois a obra relata os anos de 1889 até o período de mais ou menos 1910, sendo escrito em 1983. Essa diferença temporal mostra uma mudança no espaço social, pois os costumes mudaram. Cora Coralina mesma sabia da importância de rever e escrever sobre esse passado tendo-o vivido.

O poema "Moinho do tempo" afirma: “Geração ponte, eu fui, posso contar”, sendo que esse trecho do poema refere-se especialmente à ponte da escravidão com uma sociedade de homens livres e de uma classe média que ainda estava se habituando ao costume de não ter escravos, embora ainda tratando seus empregados como se o fossem. Nessa contraposição do passado com o presente, o eu lírico reconhece o presente como melhor, não só por não haver mais tantos resquícios da escravatura, mas também pelos costumes em geral. O poema "Normas da educação" trata especialmente do costumes de educar os filhos, onde se afirma: "Digo sempre: Jovens agradeçam a Deus todos os dias por terem nascido nesses tempos novos”. Antes dessa afirmação, o poema conta de como as crianças eram tolhidas até para comer, acabando por roubar a comida que davam aos animais e sem saber por que era assim, pois “criança não valia mesmo nada. Entendia por acaso dessas normas de Educação? Nada era natural e os menores não tinham direitos”. Nesse poema há também o relato do trato com os empregados, semelhante ao dado para as crianças, com surras e contenções.

Nessa recriação do passado, o espaço social tem uma importância grande porque ele conduz Aninha. São as diferenças entre a sociedade velha e a nova e os costumes e tradições da sociedade antiga configuradas nesse espaço social que desencadeiam o lirismo e são o principal tema desse livro. 


\section{Função social e espaço}

A função social está presente em "Vintém de cobre: meias confissões de Aninha" porque na recriação do passado se recriam também os costumes, as tradições e as lendas pertencentes não só ao interior de Minas Gerais, mas também ao Brasil.

Um dos desejos dos modernistas era o de reescrever o Brasil. Um dos exemplos são as pesquisas folclóricas de Mário de Andrade, muito usadas em "Macunaíma”, ou Guimarães Rosa, com suas viagens para o sertão para observar os costumes do povo para depois os colocar em seus livros. Escritores como estes reescreveram o Brasil através do estudo e de observações sobre o modo de vida do povo brasileiro. Cora Coralina faz a mesma coisa usando a sua experiência de vida em "Vintém de cobre: meias confissões de Aninha”, e em todos os seus outros livros, pois reescreve o Brasil, reescrevendo o modo de vida e o modo de ver o mundo do povo brasileiro, principalmente de um povo rural. Assim reescreve o que pode ser chamado de "memória coletiva” do Brasil do fim do século XIX e início do século $\mathrm{XX}$, principalmente sobre o modo de vida das mulheres desse povo.

O elemento social não fornece apenas a matéria ou o contexto das recordações, mas ele atua na formação do que é essencial na obra, sendo, portanto, um elemento estético, pois sem o fator social a obra não seria a mesma. E o que faz com que essa poesia traga essa função social é a recriação de pequenos quadros, ou o espaço onde se situam os poemas. Até mesmo não existiria a lembrança, que serviu de guia para compor o livro, sem esse espaço.

[...] o espaço é uma realidade que dura: nossas impressões se sucedem, uma à outra, nada permanece em nosso espírito, e não seria possível compreender que pudéssemos recuperar o passado, se ele não se conservasse, com efeito, no meio material que nos cerca (DELGADO, 2003, p. 285).

Por ser um elemento que desencadeia o lirismo, o espaço social deixa de ser um motivo externo e passa a ser um fator estético ou um fator interno, porque motiva e faz parte do psíquico.

Sabemos, ainda, que o externo (no caso, o social) importa, não como causa, nem como significado, mas como elemento que desempenha um certo papel na constituição da estrutura, tornando-se, portanto, interno (CÂNDIDO, 1985, p. 4).

Quando fazemos uma análise desse tipo, podemos dizer que levamos em conta o elemento social, não exteriormente, como referência que permite identificar, na matéria do livro, a expressão de uma certa época ou de uma sociedade determinada; nem como enquadramento, que permite situá-lo historicamente; mas como fator da própria construção artística, estudado no nível explicativo e não ilustrativo (CÂNDIDO, 1985, p. 7). 
Através de imagens do comum, a obra vai fazendo com que esse espaço ganhe maior significado, pois em seus poemas há o jogo direto de cenas que a princípio parecem como pequenos quadros isolados, mas o seu conjunto produz o significado. Como ocorre nas primeiras estrofes do poema "Moinho do tempo" que possuem versos com pouca ou nenhuma dependência sintática, pois pintam pequenos quadros com objetos de uma casa (fechaduras, gavetas, armários, baú), ou com cenas comuns, como um gato "fedendo pelos cantos", ou aranhas tecendo teias. O conjunto dessas cenas dá o significado de que a casa revelada era pobre e decadente, onde existiam resquícios de um passado diferente.

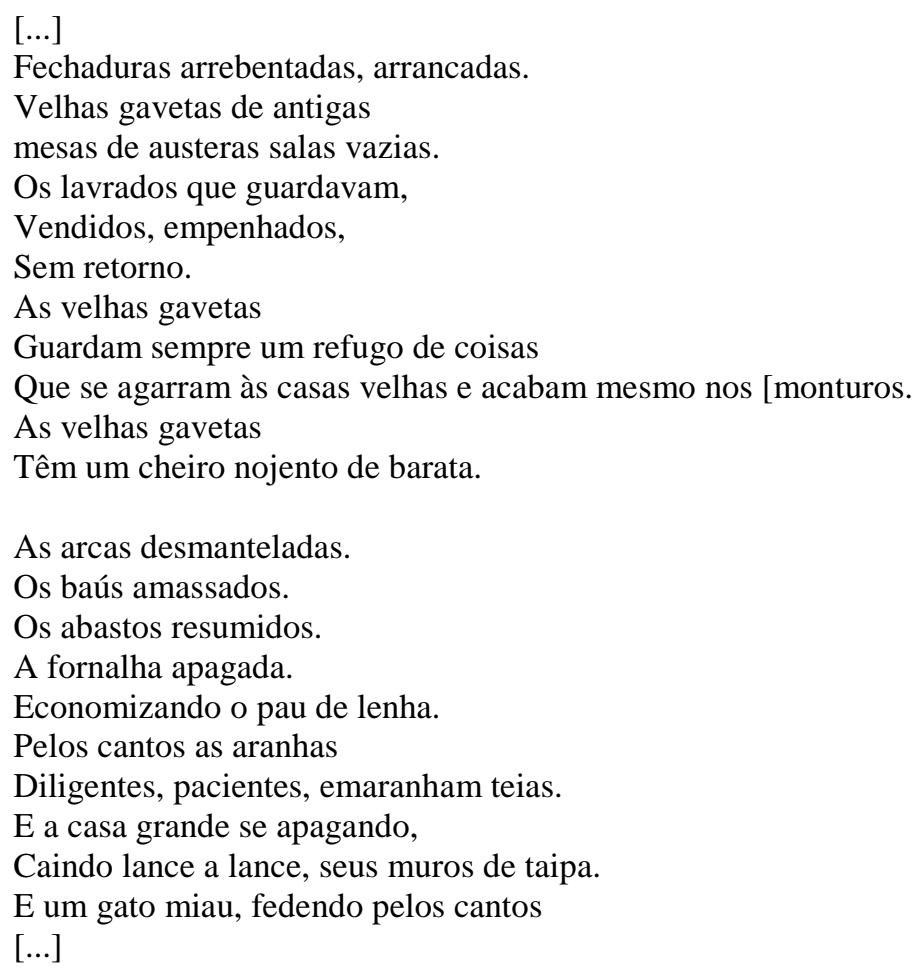

Como se pode perceber, o lirismo é construído através de fatos e imagens cotidianos desse espaço social. Como o livro é sobre a reconstrução do passado, o lirismo se volta para uma reconstrução do eu. Como se pode perceber no título do livro: "Vintém de cobre: meias confissões de Aninha”. O livro tem esse título porque remonta à infância do eu lírico e aos poucos vinténs de cobre que possuía, ou seja, relembra sua pobreza e sua vida modesta no interior de Minas Gerais e de como foi sua infância e mocidade. A explicação do que significa esse vintém de cobre está em alguns poemas, como em “O cântico de Aninha” e "Meu vintém perdido” Em “O cântico de Aninha”, o eu lírico afirma que o vintém de cobre remete ao tempo de sua criação (o que busca reconstruir em todo o livro) e a pobreza que ele inspira e que ela vivia. Depois de fazer uma apresentação do espaço, do cotidiano e do que o vintém 
significa, sendo que tudo isso remete a uma idéia de pobreza e trabalho, e do quanto se lutava para conseguir esse vintém, o poema finaliza com a significação maior desse vintém:

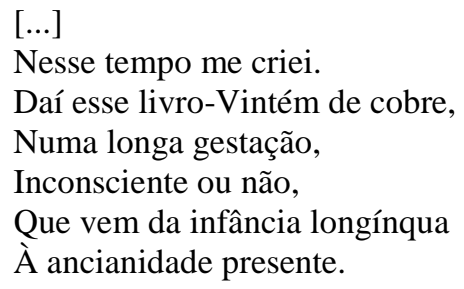

No poema "Meu vintém perdido", ocorre a busca pelo vintém de cobre, que é o vintém de felicidade de Aninha, não porque esse tempo foi feliz, mas porque essa felicidade ocorre na busca de “uma capacidade maior de ser eu mesma”, ou por uma busca pela própria identidade.

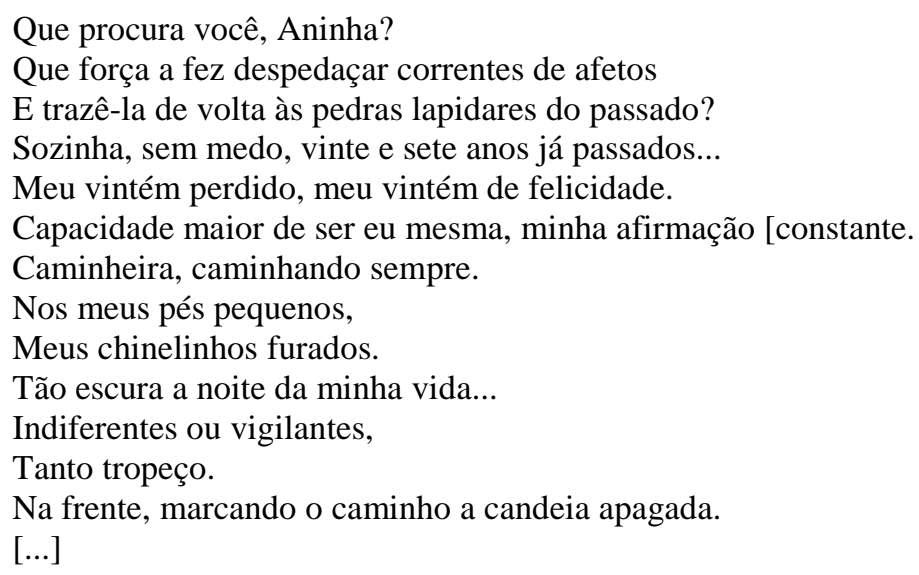

O lirismo se constrói a partir do espaço social e Aninha está completamente inserida nele, identifica-se com ele, mesmo que haja uma distância temporal entre quem escreve (Cora) sobre quem escreve (Aninha), como ocorre em poemas que tratam da sua infância (o nome Cora é mais ficcional que Aninha). No poema "Sou raiz” há essa distância temporal, mas o eu lírico ainda está inserido no espaço da gleba e nas viagens que descreve, porque isso fez parte de sua formação. Então chega a afirmar: "Eu sou a gleba e nada mais pretendo ser”. No poema “A gleba me transfigura”, vemos a mesma inserção do eu lírico no espaço rural que afirma ser ele próprio, porque seus versos tratam dele e o constroem, e esse espaço teve importância grande na sua história: "Sinto que sou a abelha no seu artesanato. Meus versos têm cheiro dos matos, dos bois, dos currais [...] Sou arvore, sou tronco, sou raiz, sou folha, sou graveto, sou mato, sou paiol e sou a velha tulha de barro".

De todas as marcas desse espaço, aquilo com que mais fortemente o eu lírico se identifica ou até em que se transfigura e exalta é a terra, porque dela depende tudo que está nesse espaço, como demonstra no poema “A gleba me transfigura”: 
$[\ldots]$

Amo a terra de um místico amor consagrado, num esponsal sublimado, procriador e fecundo.

[...]

Amo a terra de um velho amor consagrado

Através de gerações de avós rústicos, encartados.

Nas minas e na terra latifundiária, sesmeiros.

A gleba está dentro de mim. Eu sou a terra.

Identificada com seus homens rudes e obscuros,

Enxadeiros, machadeiros e boiadeiros, peões e moradores.

Seus trabalhos rotineiros, suas limitadas aspirações.

Partilhei com eles de esperanças e desenganos.

$[\ldots]$

Eu sou a terra milenária, eu venho de milênios.

Eu sou a mulher mais antiga do mundo, plantada e fecunda

No ventre escuro da terra.

Como o livro trata da reconstrução de um “eu” e esse "eu” se formou a partir de um espaço, o tratamento do psicológico (mundo interior, emoções, estado de espírito do eu lírico) se mistura com o tratamento do espaço social. No poema "Moinho do tempo", há esse caminho do espaço para o psicológico diretamente. Ele se inicia com a descrição de objetos que dão a idéia de uma casa velha e decadente, mas como se trata de fechaduras, chaves e gavetas pode ser uma alusão aos seus “guardados” da memória. Essa descrição ocupa as três primeiras estrofes e na quarta o eu-lírico já trata da influência religiosa, que pode ser vista como social e psicológica, afirmando que se apegava aos santos, mas o tempo ia passando e os santos se mostravam "cansados, enfastiados, economizando os milagres do passado", provavelmente porque o eu lírico desejava que a sua situação de pobreza mudasse. A quinta, a sexta e a sétima estrofes tratam mais do psicológico, do sonho de se casar e da demora de aparecer marido. Da oitava a décima primeira estrofe há a descrição de costumes sociais. Da décima primeira ao restante do poema, o social e o psíquico se intercalam nos versos.

Em alguns poemas o eu-lírico faz o caminho inverso, e ao invés de partir do espaço social para o psíquico, parte do psíquico para o social, mas isso não altera sua importância porque ainda assim mostra a interação entre o psíquico e o social e como o eu lírico está fundido nesse espaço, como se fossem a mesma coisa.

Como se pode observar, o social e o psíquico formam ao mesmo tempo essa poesia, mas é o social que faz com que se entenda o psíquico.

Para tratar do social, o eu lírico parte do individual para o coletivo (vida coletiva, dos costumes comuns a todos), e outras vezes do coletivo para o individual, mas de qualquer forma o coletivo e o individual estão sempre muito ligados, semelhantemente ao que ocorre nas literaturas de grupos iletrados, que se liga diretamente à vida coletiva. No poema "A gleba me transfigura” pode-se ver o coletivo e o individual completamente fundidos, pois o eu lírico 
diz que é como todos os outros moradores do campo desde o momento que se metaforiza na terra.

[...] Eu sou a terra.

Identificada com seus homens rudes e obscuros,

Enxadeiros, machadeiros e boiadeiros, peões e moradores.

Seus trabalhos rotineiros, suas limitadas aspirações.

Partilhei com eles de esperança e desenganos.

$[\ldots]$

Antônio Cândido, em seu livro "Literatura e sociedade", faz a distinção entre dois fenômenos sociais: a integração e a diferenciação. A integração ocorre quando se acentua em um indivíduo ou em um grupo a participação desses como coletividade. A diferenciação ocorre quando se acentua no indivíduo o que ele tem de especial, diferente do grupo. Em alguns poemas, o eu-lírico parte de um único eu e dá o maior significado poético ao que esse eu tem em comum com outros, mostrando, portanto, a sua integração. Em outros momentos, o poema parte do coletivo para mostrar o que um único eu tem de particular, fazendo, portanto, sua diferenciação.

No poema "Menina mal amada”, Aninha conta de como foi diferente das outras crianças. Relata rejeições, solidão, o quanto apanhou e se humilhou. Dessa forma revela seu estado mental e também do costumes sociais que lhe eram impostos, e faz a sua diferenciação do espaço, pois mostra como não se adequava a esses costumes.

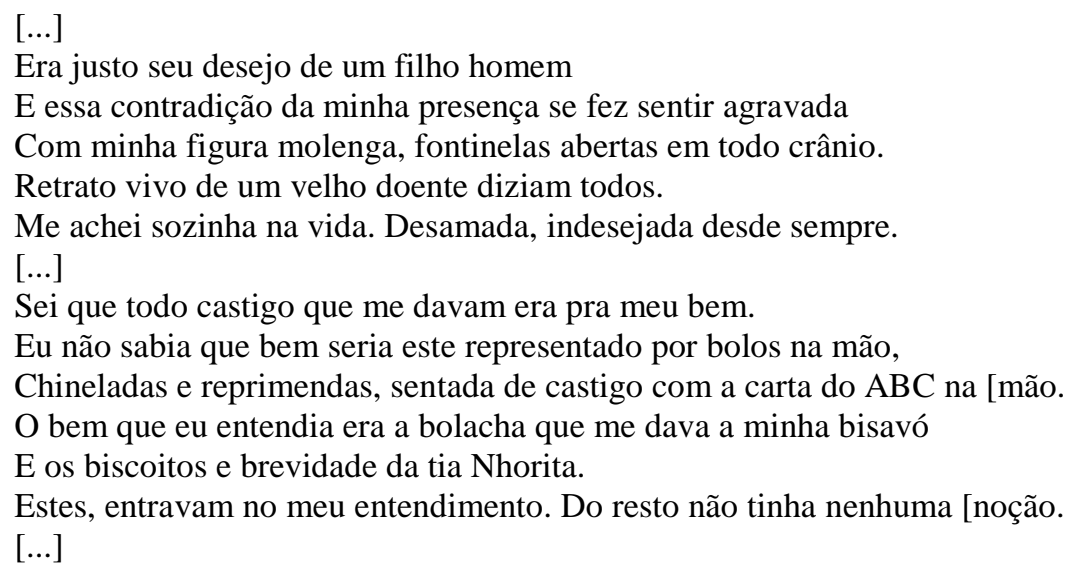

Já no poema "Sou raiz" ocorre a integração do eu lírico no espaço social, porque procura mostrar o quanto aprendeu com a convivência do povo mais humilde do interior de MG, e do quanto faz parte desse povo.

[...]

Velhas jardineiras do passado...

Condutores e cobradores, vós me levaste de mistura

Com os pequenos e iletrados, pobres e remendados... 
Deste-me o nível dos humildes em tantas lições de vida.

Passante das estradas rodageiras, boiadeiros e comissários,

Aqui fala a velha rapsoda.

[...]

Tratando das possíveis influências do meio sobre a obra de arte, Antônio Cândido trata de duas maneiras de ver essa influência. Primeiramente podemos ver em que medida a arte é expressão da sociedade. Também podemos ver em que medida a obra é social. A distinção entre os dois modos é que experiências artísticas que expressam a sociedade mostram seus costumes, particularidades, e as experiências artísticas sociais são as preocupadas com problemas sociais. Em "Vintém de cobre: meias confissões de Aninha" se pode ver os dois tipos de experiências. As experiências que expressam a sociedade geralmente ocorrem quando há a integração do eu-lírico com o coletivo.

No poema "Ofertas de Aninha (Às lavadeiras)" há a experiência de expressar uma parte da sociedade, pois o poema é uma homenagem às lavadeiras. No conjunto de todas as obras de Cora Coralina há várias homenagens a elas a outras vidas menosprezadas. Foi expressando socialmente essas vidas que a autora fez críticas aos costumes. Nos dois primeiros versos do poema, há a descrição do ambiente de trabalho e o dia a dia dessas lavadeiras. No último verso ocorre um elogio ao seu modo de vida trabalhador, pois elas nunca se cansam e são gratas a Deus pelo que têm.

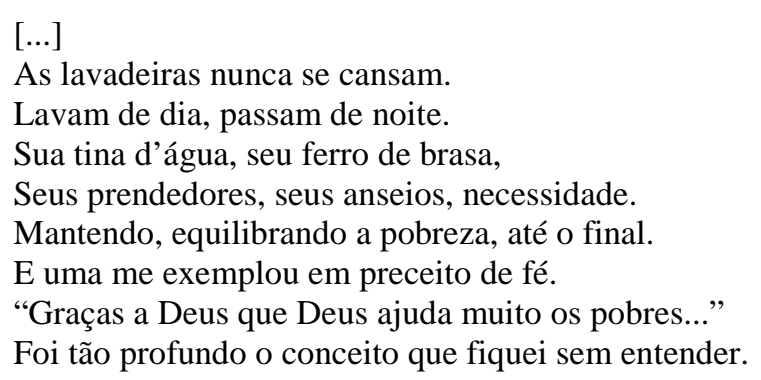

No poema "Três deveres a cumprir" também há essa busca de mostrar uma parte da sociedade e de mostrar o poético nessas vidas. O poema procura mostrar como os trabalhadores rurais não têm preguiça de trabalhar e como são solidários uns para com os outros mesmo na pobreza, afirmando que no seu modo de vida, de "trabalho constante", "a vida tem a melhor expressão”. Na última estrofe há a defesa da idéia de que é preciso dar terras aos homens do campo e ajudar esse homem a viver lá, para que não tentem viver na cidade, porque então não haveria mais o que chama de “a vida na sua melhor expressão”, com trabalho e solidariedade. 
$[\ldots]$

As autoridades têm três deveres a cumprir: dar terra ao homem da [lavoura, Fixá-lo na gleba. Não consentir no seu desligamento do meio onde foi [criado, Ajudá-lo no possível. Ali na terra está a harmonia e a integridade Do grupo tribal. Tangidos para a cidade, é a desagregação familiar, A desilusão, a incompatibilidade urbana, o desarranjo total, a perdição. Nada do que imaginou se realiza e a unidade é destruída.

Antônio Cândido trata de três funções da literatura: função total, função social e função ideológica, sendo que as três juntas permitem compreender a obra literária em sua amplitude.

A função total da obra literária ocorre quando o sistema simbólico transmite uma determinada visão de mundo por meio de instrumentos expressivos que se adequem. "Ela exprime representações sociais e individuais que transcendem a situação imediata, inscrevendo-se no patrimônio do grupo” (CÂNDIDO, 1985, p. 45). A função total é a função que faz com que uma obra de arte seja atemporal e universal, porque é ela que faz com uma obra se desligue de um determinado tempo e de um determinado espaço e os transcenda.

A obra "Vintém de cobre: meias confissões de Aninha” está bastante atrelada ao seu tempo (principalmente na diferença entre dois tempos) e no ambiente rural, fazendo sua função social. Mas mesmo assim ela tem significado fora desse contexto, porque aborda temas universais, como a valorização do trabalho, da terra e dos humildes, o que realiza a função total da obra, fazendo com que haja a poeticidade pela integração entre a linguagem e o conteúdo, mesmo quando a obra é lida fora desse contexto e depois de muitos anos de publicação. No poema “Confissões Partidas”, o eu lírico trata de como os homens nunca conseguem dizer tudo que pensam e tudo o que querem dizer. Essa impossibilidade de dizer toda a verdade pode ser associada com a forma com que o eu lírico descreve ter sido a sua educação, quando foi bastante tolhida e presenciou vários preconceitos, mas independente da educação, todos os homens passam pela mesma situação de não conseguirem dizer tudo o querem. Nesse poema o eu lírico se mostra angustiado por essa impossibilidade. Essa angústia se mostra principalmente na primeira estrofe. No segundo verso da segunda estrofe e nos terceiro e quarto versos da quarta estrofe, o eu lírico pergunta quem consegue dizer toda a verdade. A repetição da pergunta em lugares distantes do poema faz com que se acentue a angústia do eu lírico pela busca da verdade inteira. A segunda estrofe trata das conveniências e do quanto elas impedem a verdade. A terceira estrofe destaca o que são esses pensamentos escondidos. Na quarta estrofe, o eu lírico trata das conseqüências desses pensamentos: que são como "algemas mentais", que aprisionam. Na quinta estrofe, o que era chamado de conveniência passa a se chamar “medo”. 
Confissões partidas

Quisera eu ser dona, mandante da verdade inteira e nua,

Que nua, consta a sabedoria popular, ela está no fundo de um poço fundo,

E sua irmã mentira foi a que ficou em cima beradiando.

Quem dera a mim esse poder, desfaçatez, coragem de dizer verdades...

Quem as tem? Só o louco varrido que perdeu o controle das conveniências.

Conveniências... palavras assim de convênio, de todos combinados,

Força poderosa, recriando a coragem, encabrestando a vontade.

Conveniência... irmã gêmea do preconceito, encangados os dois,

Puxando a carroça pesada de meias verdades.

Confissões pela metade...

Quem sou eu para as fazer completas?

Reservas profundas, meus reservatórios secretos, complexos,

Fechados, ermos, compromissos íntimos e preconceitos vigentes, arraigados.

Algemas mentais, e tolhida, prisioneira, incapaz de despedaçar a rede.

Onde se debate o escamado da verdade...

Qual aquele que em juízo são, destemeroso dos medos

Para dizer mais do que as meias dissimuladas, esparsas?

A gente tem medo dos vivos e medo dos mortos.

Medo da gente mesmo.

Nossas covardias retardadas e presentes.

Assim foi, assim será.

A função social consiste no relacionamento mais direto da obra com o social, buscando interferir no ambiente e reforçar a consciência dos valores sociais. Ela independe da vontade ou da consciência dos autores. Ela ocorre pela natureza da obra e pelo costume de recepção desse tipo de obra em um local determinado.

Em "Vintém de cobre: meias confissões de Aninha” a função social ocorre na maioria dos poemas, pois Cora revela uma realidade pessoal e/ou social que discute um tempo/espaço e suas peculiaridades e ao fazer isso ela está interferindo no olhar sócio-histórico sobre esse tempo modificando-o. A autora está, sob seu prisma, revelando o mundo ao mundo, está inserida em seu contexto, expressa uma visão de mundo que é também patrimônio social. A título de exemplo, essa função ocorre também quando o eu lírico mostra o modo de vida dos povos mais humildes. Como ocorre no poema "Coisas de Goiás: Maria”, que trata da vida de uma senhora chamada Maria, a "Maria grampinho" e "Maria sete saias” que vivia como “muitas que rolam pelo mundo”, na pobreza, sem ter onde morar e sem ter ninguém por ela, sem ter mesmo família e que ninguém sabia de onde teria vindo. Maria é apresentada como uma figura lendária na cidade de Goiás e que era chacoteada pelo povo, principalmente pelo modo de se vestir. Maria já possuía usucapião da Casa Velha da Ponte, que há muito vivia lá e contam que "Maria tinha até leitura e fazia crochê, ponto de marca, costurava”. Uma senhora chamada Maria viveu muitos anos em Goiás com Cora Coralina e depois que Cora Coralina 
morreu, Maria continuou vivendo lá até morrer também, sendo que ainda há alguns de seus pertences na casa.

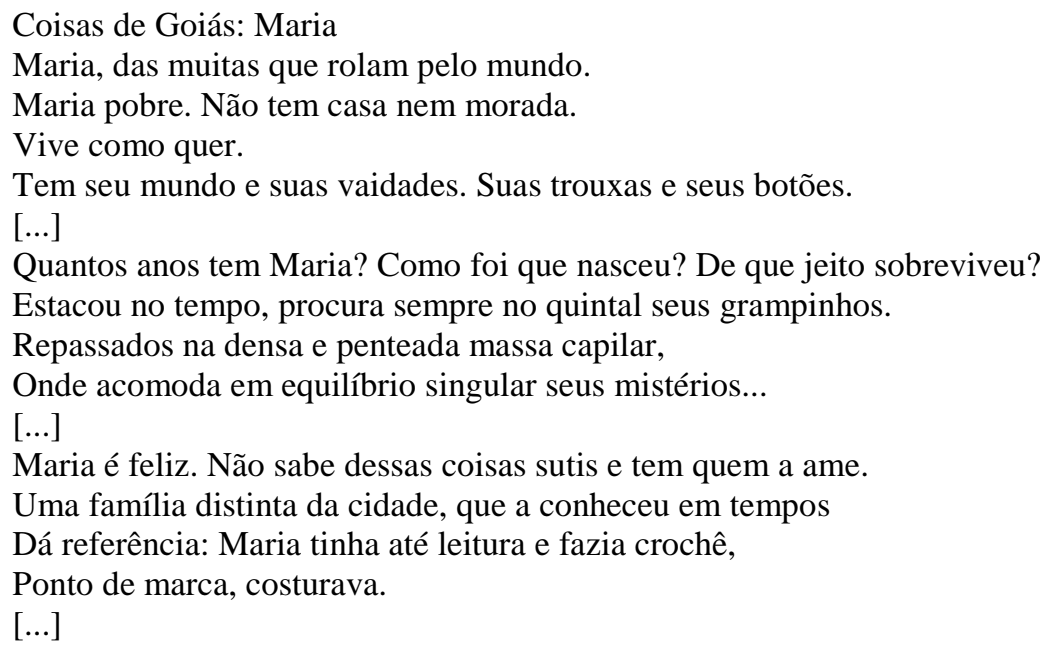

O poema “O carreiro Anselmo”, também ocorre essa função social, pois descreve o trabalho e o modo de vida desse carreiro. O poema mostra como os camponeses se apegam a uma determinada terra, que muitas vezes é propriedade de outra pessoa, e aos animais dessa terra. Isso ocorre através da história do carreiro Anselmo, que trabalhava na fazenda Paraíso e foi um dos únicos moradores que não quis sair de lá devido à decadência da fazenda. Anselmo ficava lá, porque tinha carinho por aquela terra e pelos animais e só saiu no dia de entregar os bois para o curral, porque não queria presenciar isso.

\section{$[\ldots]$}

Mandou que Anselmo trouxesse os bois para a entrega no curral.

Aí, falou o velho vaqueiro: "Inhô, dá licença. Isso num tenho corage,

Num faço não. Dá licença de’u tirá meus cacos e saí premero.

$[\ldots]$

Em ambos os poemas não apenas se evidencia o modo de vida dessas pessoas, mas também se mostra uma visão de mundo, revelando os costumes e a mentalidade dessas pessoas. Em "Coisas de Goiás: Maria” a poeticidade ocorre através do modo de vida de Maria, assim como em "O carreiro Anselmo", associado também ao seu apego à terra e principalmente aos animais.

A poeticidade ocorre devido a essa visão de mundo revelada e também na linguagem condizente com a realidade em destaque. A linguagem simples e corrente do eu lírico se adapta com a situação corriqueira que está narrando e com a realidade destacada. O uso de palavras e expressões como "Inhô, dá licença. Isso num tenho corage. Num faço não. Dá licença de’u tira meus cacos e saí premero” também demonstra a situação sócio-histórica do 
personagem Anselmo, pois está em uma variação lingüística que pertence apenas aos sertanejos e pobres.

Algumas vezes essa função social ocorre quando o eu lírico trata da sua vida particular, pois contando o que aconteceu na sua vida trata do modo de vida, da linguagem e do modo de ver o mundo de um povo rural e humilde.

Esse olhar para dentro de si, para a própria vida e para o próprio eu, que revelam o modo de pensar e de viver de uma determinada sociedade, Adorno chama de engajamento, em sua “Conferência sobre Lírica e sociedade”. Esse engajamento, quando adquire valor poético, faz com que a obra passe a ter participação no universal.

Esse mergulho para dentro de si faz brotar uma linguagem que está arraigada no fundo do ser do eu lírico, pois é a linguagem de sua infância que é usada nos poemas, mesclada com o tratamento da realidade desse tempo.

A função ideológica é definida por Antonio Cândido como tudo aquilo que é voluntário na obra, tanto na produção como na recepção, são aquelas partes que contém um sistema pronto de idéias. Em “Vintém de cobre: meias confissões de Aninha” há essa função ideológica, mas não no sentido político, religioso ou filosófico, mas no sentido que Antonio Cândido definiu, como sendo uma parte voluntária com um sistema pronto de idéias. Essa função pode ser observada na última estrofe do poema "Três deveres a cumprir”, quando o eu lírico defende que se deve ajudar os trabalhadores rurais a permanecerem no campo e que na cidade tudo piora.

Em “Vintém de cobre: meias confissões de Aninha”, e em toda a obra poética de Cora Coralina, se pode perceber também pelo lado social o compartilhamento do eu lírico com as dores humanas e com as pessoas que a sociedade coloca à margem.

A identificação com os que vivem a margem já pode ser observada quando a autora dá voz ao eu lírico como Cora Coralina, que trazia a imagem de uma velha que vendia doces, e como uma criança (Aninha), porque estas também vivem na margem.

Quando a voz do eu lírico assume a voz dos excluídos, ele reorganiza a história oficial, porque coloca em evidência essa voz, e não a do discurso dominante. Assim mostra a voz dos que sofrem os preconceitos, a pobreza e toda uma sorte de males sociais.

Pode-se chamar de sensibilidade sociológica essa opção temática de Cora Coralina e escritores como Lima Barreto pelos seres marginalizados. Essa opção estaria atrelada com as mudanças que estavam ocorrendo no Brasil pela sua modernização e formação de uma sociedade capitalista, pois ela seria uma vinculação com as condições de emergência então surgidas. Como ocorreu com Lima Barreto, essa opção pelos marginalizados em Cora 
Coralina foi fundamental para o seu posicionamento crítico. Nessa sensibilidade sociológica é possível perceber o engajamento do eu lírico. Sartre chamou de engajamento essa opção consciente dos escritores de procurar mostrar o mundo ao mundo em suas obras, tirando a inocência desse mundo. Embora Sartre considere que na poesia é impossível o engajamento, em “Vintém de cobre: meias confissões de Aninha” há o mundo sendo revelado ao mundo, na atitude de engajamento que desejava Sartre, quando mostra o modo de vida dos sertanejos e humildes, juntamente com a própria inserção do eu lírico nessa realidade.

Também se pode fazer a relação da poesia de Cora Coralina com a poesia de resistência, definida por Alfredo Bosi. Poesia de resistência é aquela que representa uma forma de resistência aos discursos dominantes. Segundo Bosi, toda poesia moderna tem um pouco de resistência, principalmente quando assume a voz dos oprimidos, é o que ocorre na obra de Cora Coralina em muitos poemas. Em "Vintém de cobre: meias confissões de Aninha” isso ocorre muito porque a voz que mais se assume é a voz de uma criança, que na nossa sociedade é colocada na margem, principalmente a menina Aninha, por viver em ambiente rural e ser rejeitada pelos seus.

\section{Considerações finais}

Em "Vintém de cobre: meias confissões de Aninha” a função social (ou o engajamento, conforme Adorno) ocorre através de um mergulho no eu, pois ao reconstruir sua infância, o eu lírico mergulha dentro de seu mundo interior, sua memória infantil e revela o modo de pensar de um povo humilde. Com esse mergulho para dentro de si também revela o modo de vida desse povo. Olhando para dentro de si, o eu lírico também olha para os seus semelhantes que fizeram e fazem parte de sua história, e dá especial atenção aos que vivem à margem da sociedade: como as lavadeiras, trabalhadores rurais, a Maria "grampinho”, as mulheres (porque o eu lírico assume uma voz feminina) e as crianças (porque conta a história de uma criança: Aninha).

A linguagem e o estilo dos poemas também colaboram com essa função social porque a linguagem usada é, intencionalmente, de uma variação dos povos humildes e o estilo de contar casos é comum na região e no tempo que a obra retrata.

Dessa função social também se depreende sua função histórica, porque retrata os costumes e a mentalidade de um determinado tempo (principalmente do final do século XIX e de uma parte do século XX). 


\section{Referências}

ADORNO, Theodor W. In: BENJAMIN, Walter e outros. Textos escolhidos. São Paulo: Abril Cultural, 1975. p. 201-214. (Os Pensadores, 48).

BRITTO, Clóvis Carvalho ; SANTOS, Robson dos. Representações sociais do rural na poética de Cora Coralina. Hispanista, v. 10, n. 38, p. 1-14, jul./ago./set., 2009.

CAMARGO, Goiandira de F. Ortiz de. Poesia e memória em Cora Coralina. Signótica, v. 14, n. 1, 2002.

CÂNDIDO, Antônio. Literatura e sociedade: estudos de teoria e história literária. 7. ed. São Paulo: Ed Nacional, 1985. p. 7.

CORALINA, Cora. Vintém de cobre: meias confissões de Aninha. 2. ed. Goiânia, Ed. da Universidade Federal de Goiás, 1984.

DELGADO, Andréa Ferreira. A invenção de Cora Coralina na batalha das memórias. Campinas: Ed. Unicamp, 2003. p. 285.

ELIOT, T. S. A função social da poesia. In: De poesia e poetas. São Paulo: Brasiliense, 1991. O GLOBO. "Poetisa de 93 anos (e “todas as idades”) lança terceiro livro”. São Paulo, 28 fev. 1982, p. 27 